\title{
Improving Durability Properties of Concrete by using Quarry dust and Waste Plastic as Fine Aggregate
}

\author{
B.V.Bahoria, D.K.Parbat, Vikrant Vairagade
}

\begin{abstract}
The degree of this view is to redesign the undertaking capacity of the supportable use of quarry soil, and to discover any gaps in present day-day know-how. The time allotment affordable usage construes the utilization of quarry buildup to their complete capacity to meet the dreams of the overwhelming, on a comparative time as on the vague time keeping up customary resources and finding strategies to restrain the natural impacts related both with quarry fines gathering and use. Solid mixes had been casted the use of standard stream sand and in evaluation with $25 \%, 50 \%, 75 \%$, $100 \%$ open entryway with quarry soil in blend with waste plastic in fabriform. . The development of quarry dust near to squander plastic certainly improved the strong structure homes with respect to power and vulnerability block. The development of significant worth quarry dust with ldpe as waste plastic in strong incited impelled system densification in assessment to conventional concrete. System densification has been considered abstractly through petro graphical test using virtual optical microscopy. The shape modified into evaluated using SEM in quarry dust and ldpe composites.
\end{abstract}

Keyterms:typical sand; quarry dust; waste plastic, SEM evaluation, RCPT, Cracked

\section{INTRODUCTION}

Within the continuous beyond awesome undertakings had been made for the effective utilization of various mechanical reactions, (as an instance, fly ash, silica fume, rice husk powder, foundry waste) to save environmental defilement. In like manner, an non-compulsory hotspot for the capability substitution of regular sums in bond has improved great thought. Consequently low priced examinations have been directed to find out the sensibility of quarry dust in ordinary bond. Pacheco-Torgal et al (2002) handled the durability houses of concrete with remarkable styles of aggregates. They located that there was nearly no refinement on robust power parameters at the same time as made either with stone, gabbro or calcareous coarse aggregate. The consequences procured for vacuum water upkeep, oxygen and water vulnerability of each unmarried robust blend confirmed a similar solicitation of diploma. This exhibited the concept of concrete mixes made with exclusive aggregates appeared commonly equal, in all instances. Squat and Jason Philips (2009) investigated each circulate sand and created limestone sand used as fine combination in strong mixes. The mixes display comparable value and

Revised Manuscript Received on April 12, 2019.

B.V.Bahoria,Assistant Professor, Rajiv Gandhi College of Engg.\&Research,Nagpur , India (Email: boskey.bahoria@ gmail.com)

D.K.Parbat,Professor, Govt.polytechnic,Bramhapuri, India, (Email: parbatdk@gmail.com)

Vikrant Vairagade,Assistant Professor PCE, Nagpur, India (Email: vikrantvairagade@gmail.com) stepped forward the sturdiness homes. Bayasi and Zeng (1993) (1) investigated the effect of reused plastic on the vulnerability of concrete. They assumed that $19-\mathrm{mm}$ polypropylene fibers interior and out prolonged the permeability of bond with a clashing impact on the amount department of inclined voids; 12.7-mm lengthy strands alternatively extended the vulnerability of cement and will at the same time as all is said in completed decrease the volume of inclined voids. Zainab Z. Ismail *, Enas A. ALHashmi, 2007(2).In each other exam, the sturdy crafted from stone buildup, of spherical $48 \mathrm{MPa}$ top notch, demonstrated $10 \%, 24 \%$, and $26 \%$ higher extraordinary in weight, strain and flexural strain, independently over the managed concrete. With the manner in which that strong includes awesome imperfections and littler scale elements the use of waste plastics in present exam has been joined. The fast inciting of littler scale breaks beneath an related weight is seen as liable for the low inflexibility of concrete. It's far cheap to count on that the strength further as the flexural nature of concrete may be impressively extended via using displaying solidly remoted fibers. Those strands could capture the unfold of littler scale elements, alongside those lines conceding the begin of flexible breaks and growing the ability of the material. Research has been completed to analyze using quarry fines in diverse robust packages. The global center for Aggregates studies (ICAR) perceived using littler scale fines (debris beneath seventy five $\mu \mathrm{m}$ ) in bond. Studies advised that faux first-class all out mortars with immoderate fines content had higher flexural exceptional, advanced scratched zone problem, higher unit weight and decrease vulnerability in view of filling of pores with scaled down scale fines. Thusly concrete can be brought using maximum of the mixture, along with scaled down scale fines from 7 to $18 \%$ without using admixtures .Ahn and Fowler, 2001(3,4) , 2002 Hanson(five,6) taken into consideration assistant robust the use of $12 \%$ unseparated sandstone quarry fines. The issue is being sold as standard C35 exceptional concrete (35 N/mm2). Anyhow consequences exhibited that the character of a whole aspect would be extensively higher than $35 \mathrm{~N} / \mathrm{mm} 2$ following 28 days. From this time ahead, it became propelled that, if the filler material become to get replaced, and after that a incredible deal better substance of the coarser grained cloth have to be mixed. 


\section{Studies importance}

The essential attention of the prevailing work was to methodicallly take a look at the impact of price substitution of widespread sand by means of way of quarry residue and waste plastic (ldpe) in fabriform as $0 \%, 25 \%, 1 / 2$, seventy five $\%$, and $100 \%$ totally on the fine houses of concrete. The exam grow to be finished on M30 grade concrete with 0 .Five water bond volume. Waste plastic grow to be combined as 2, four, 6 , and eight $\%$ close by quarry buildup to make entire blends. Waste plastics were melded in order to enhance mechanical residences of concrete. Nice estimations were assessed the usage of break up vulnerability and fast chloride permeability test structures. Damaged vulnerability of bond is a huge diploma selected on this exam which gives a veritable estimation at the permeability residences of concrete below focused on conditions. Powders of microfines had been destitute down using Scanning electron amplifying focal aspect (SEM) imaging became completed on remarkably masterminded microfine assessments. The use of SEM engaged the microfines to be visible at better goals than viable with an optical amplifying focal point.

\section{RESULTS \& DISCUSSION}

SEM joined with EDS can be a resounding machine for ostensibly taking a gander at a particle that is too little to even don't forget nighttime don't forget being visible beneath an optical amplifying device. The SEM works by means of pointing an electron bar at the out of doors of the model. Proper when the electron bar strikes a strong article, the electrons are each scattered or held; the social affair of those responses is what outlines the SEM photo. Any electrically conductive article may be minutely tested for this reason (Sarkar et al., 2001) (07). EDS recognizes the segments found in a precedent problem to the distinguishing evidence of $\mathrm{x}$-bars released through that version. Every segment has a hallmark radiation from the electron column because of each component's trademark imperativeness function. The $\mathrm{x}$-shaft photons transmitted with the resource of the model are gathered with the aid of EDS and modified over to outstanding "exams" at each surge voltage. "The hard and speedy wide variety of strategies a selected section is in appreciate to the proportion of that section gift inside the article". More potent photographs all for SEM can be awful proper down to pick out out a couple of variables that would relate to the show of littler scale fines in bond. The segments found inside the material from EDS observe are regarded desk 1, 2, 3. The SEM pictures for sample1, sample2, sample3 below severa improvements degrees are confirmed up in figures as seeks after.

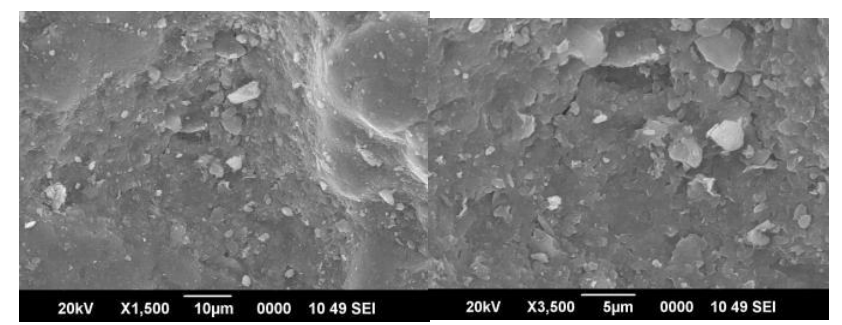

Figure 1.SEM-EDS for natural sand under X1500, X7000 magnification range

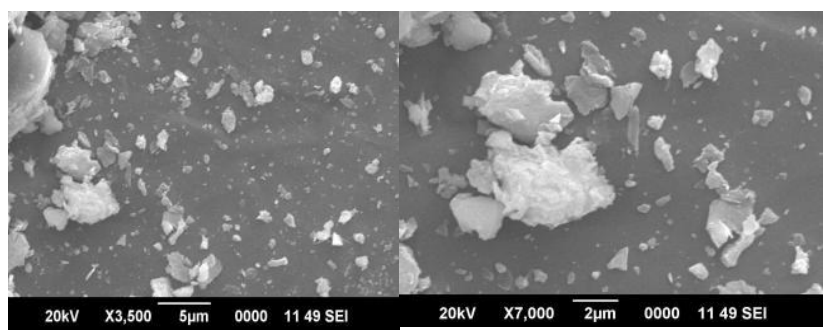

Figure 2. SEM-EDS for Quarry dust under X1500, 3500 magnification range

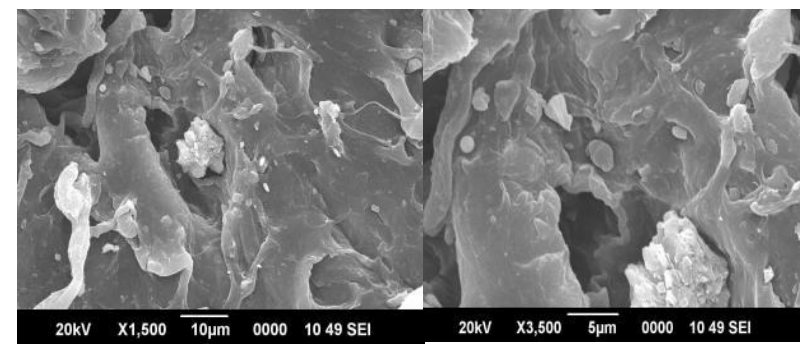

Figure 3. SEM-EDS for waste Idpe under X1500,3500 magnification range

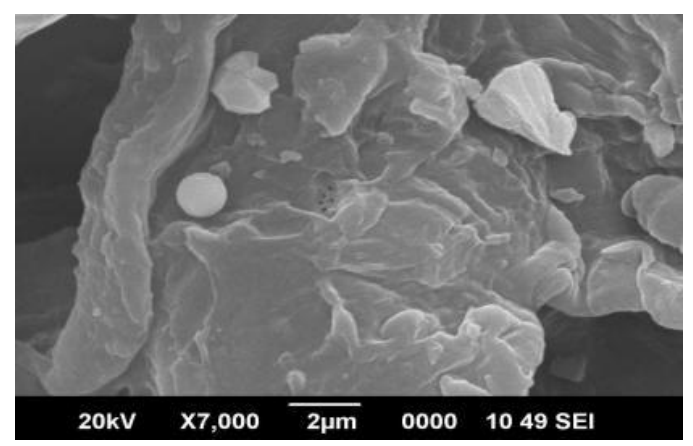

Figure 4.SEM-EDS for waste ldpe under X7000 magnification range

Table 1.Elements found in EDS Analysis (ICAR-107)

\begin{tabular}{|c|c|}
\hline Aggregate & Elements found in EDS \\
\hline$\overline{\text { NS̄ói }}$ & $\mathrm{Ca}, \mathrm{Pd}, \mathrm{C}, \overline{\mathrm{O}}, \overline{\mathrm{P}}, \overline{\mathrm{Zr}}, \overline{\mathrm{Mg}}, \mathrm{Al}, \mathrm{Si}, \mathrm{Fe}, \mathrm{Au}$ \\
\hline PF01 & $\mathrm{C}, \mathrm{O}, \mathrm{Mg}, \mathrm{Ca}, \mathrm{P}$ \\
\hline TR02 & $(\mathrm{Si}, \mathrm{Cl}$ trace $)$ \\
\hline
\end{tabular}

Table 2. Elements found in EDS Analysis of Natural sand, Quarry dust Natural sand

\begin{tabular}{|c|c|c|}
\hline Element & Weight $\%$ & Atomic\% \\
\hline $\mathrm{C} \mathrm{K}$ & 4.03 & 6.13 \\
\hline $\mathrm{OK}$ & 64.01 & 73.15 \\
\hline $\mathrm{Al} \mathrm{K}$ & 0.3 & 0.2 \\
\hline Si K & 31.13 & 20.27 \\
\hline \multirow{2}{*}{$\mathrm{Ca} \mathrm{K}$} & 0.53 & 0.24 \\
\hline & Quarry dust & \\
\hline Element & Weight $\%$ & Atomic\% \\
\hline C K & 2.78 & 5.29 \\
\hline $\mathrm{OK}$ & 40.64 & 58.02 \\
\hline $\mathrm{Na} \mathrm{K}$ & 1.45 & 1.44 \\
\hline $\mathrm{Mg} \mathrm{K}$ & 3.09 & 2.9 \\
\hline $\mathrm{Al} \mathrm{K}$ & 5.34 & 4.52 \\
\hline Si K & 18.53 & 15.07 \\
\hline
\end{tabular}




\begin{tabular}{|c|c|c|}
\hline Ca K & 6.81 & 3.88 \\
\hline Ti K & 2.28 & 1.09 \\
\hline Fe K & 19.08 & 7.8 \\
\hline
\end{tabular}

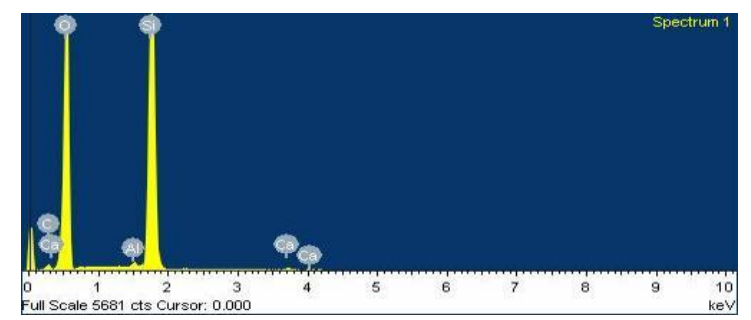

Figure 5. EDS Analysis of Natural sand

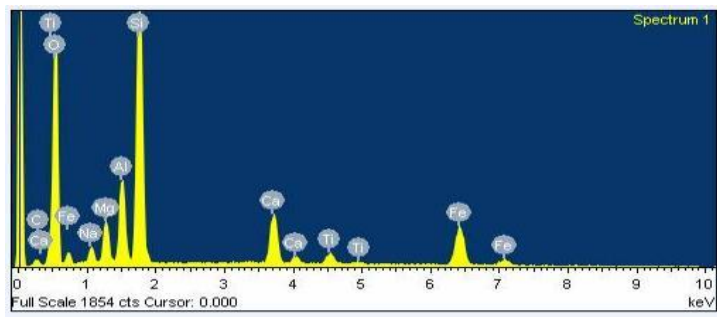

Figure 6. EDS Analysis of Quarry Dust

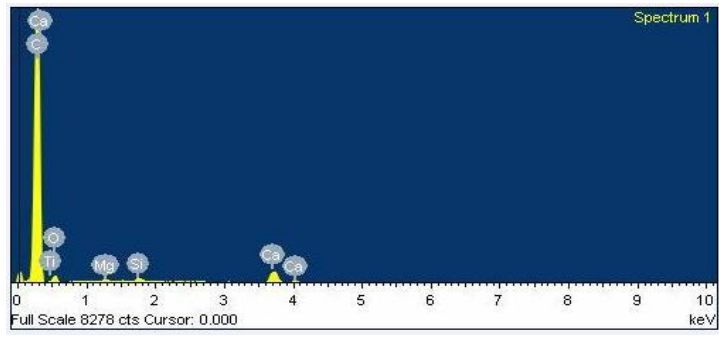

Figure 7. EDS Analysis of Waste Plastic (ldpe)

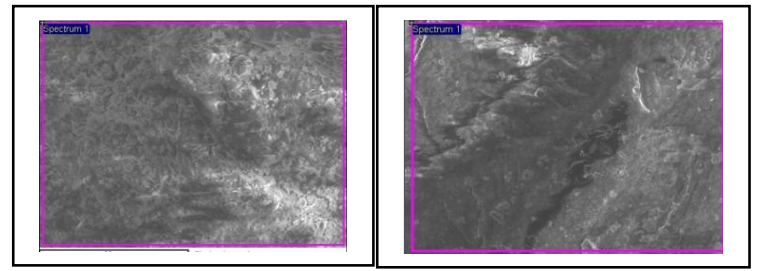

Figure 8 .EDAX Image of Natural, Image of Quarry Dust

Table 3. Elements found in EDS Analysis of Waste plastic (LDPE)

\begin{tabular}{|c|c|c|}
\hline Element & Weight\% & Atomic\% \\
\hline $\mathrm{C} \mathrm{K}$ & 4.03 & 6.13 \\
\hline $\mathrm{O} \mathrm{K}$ & 64.01 & 73.15 \\
\hline $\mathrm{Al} \mathrm{K}$ & 0.3 & 0.2 \\
\hline $\mathrm{Si} \mathrm{K}$ & 31.13 & 20.27 \\
\hline $\mathrm{Ca} \mathrm{K}$ & 0.53 & 0.24 \\
\hline Totals & 100 & \\
\hline
\end{tabular}

DURABILITY EVALUATION IN CONCRETE USING CRACKED PERMEABILITY AND CHLORIDE PERMEABILITY TEST

the fast chloride penetration check changed into carried out as regular with ( ASTM C 1202-1979) with a concrete disc specimen of duration $100 \mathrm{mmdiameter}$ and 50mmthick. This take a look at method changed into beneficial for the dedication of the electrical conductance of concrete to provide a fast indication of its resistance to the penetration of chloride ions penetration of chloride ions. The take a look at method consisted of tracking the quantity of electrical modern handed via cylinders for a 6-hour period (log time), and recording became maintained at every 30-minute c programming language. The cracked permeability of concrete changed into decided in accordance with (IS 3085 1965).Permeability have become decided in simple and quarry dirt concrete with the aid of preliminary loading implemented at the concrete specimens and measuring the weight of concrete received because of ingress of water upon micro cracking. A steady pressure of five $\mathrm{kg} / \mathrm{cm} 2$ have become given for all the concrete combinations, and the reading in the graduated glass limb of the concrete permeability check setup was referred to for the amount of water coming into the cracked specimen.

Table 4. RPCT Values for Various combinations of M30 concrete

\begin{tabular}{|c|c|c|c|}
\hline $\begin{array}{l}\text { Grade of } \\
\text { concrete }\end{array}$ & $\begin{array}{c}\text { MIX } \\
\text { IDENTIFICATION }\end{array}$ & $\begin{array}{c}28 \\
\text { days } \\
\end{array}$ & $\begin{array}{r}90 \\
\text { days } \\
\end{array}$ \\
\hline & & \multicolumn{2}{|c|}{$\begin{array}{l}\text { RCPT charge } \\
\text { passed for } 6 \mathrm{hrs} \\
\text { (coulombs) }\end{array}$} \\
\hline \multirow{21}{*}{ M30 } & M100-0-0 & 1080 & 1000 \\
\hline & M75-25-0 & 1060 & 990 \\
\hline & M75-23-2 & 1040 & 980 \\
\hline & M75-21-4 & 1020 & 960 \\
\hline & M75-19-6 & 1000 & 900 \\
\hline & M75-17- 8 & 990 & 880 \\
\hline & M50-50-0 & 980 & 860 \\
\hline & M50-48-2 & 970 & 840 \\
\hline & M50-46-4 & 950 & 820 \\
\hline & M50-44-6 & 930 & 800 \\
\hline & M50-42-8 & 920 & 780 \\
\hline & M25-75-0 & 900 & 760 \\
\hline & M25-73-2 & 890 & 750 \\
\hline & M25-71-4 & 880 & 730 \\
\hline & M25-69-6 & 870 & 700 \\
\hline & M25-67-8 & 860 & 690 \\
\hline & M0-100-0 & 850 & 765 \\
\hline & M0-98-2 & 820 & 745 \\
\hline & M0-96-4 & 800 & 730 \\
\hline & M0-94-6 & 780 & 710 \\
\hline & M0-92-8 & 750 & 690 \\
\hline
\end{tabular}

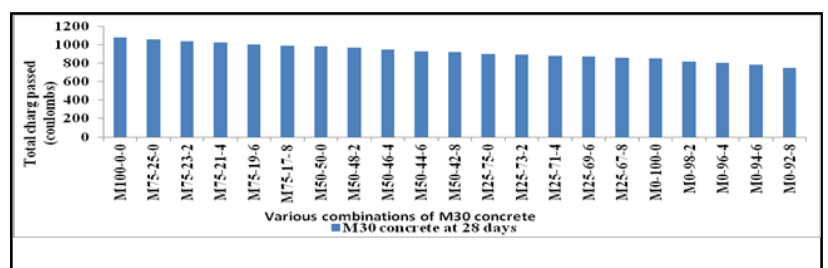

Figure 9. RPCT for M30 concrete at 28 days 


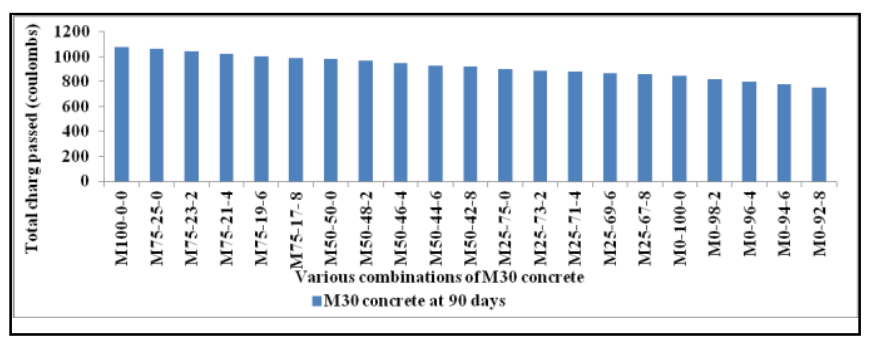

Figure 10. RPCT for M30 concrete at 90 days

Table 5 Coefficient of permeability for M30 concrete

\begin{tabular}{|c|c|c|c|}
\hline $\begin{array}{l}\text { Grade of } \\
\text { concrete }\end{array}$ & $\begin{array}{c}\text { Mix } \\
\text { Identification }\end{array}$ & 28 days & 90 days \\
\hline & & \multicolumn{2}{|c|}{$\begin{array}{c}\text { Coefficient of } \\
\text { permeability }\left(10^{-12} \mathrm{~m} / \mathrm{s}\right)\end{array}$} \\
\hline \multirow{21}{*}{ M30 } & M100-0-0 & 4.500 & 2.500 \\
\hline & M75-25-0 & 4.450 & 2.450 \\
\hline & M75-23-2 & 4.300 & 2.300 \\
\hline & M75-21-4 & 4.250 & 2.250 \\
\hline & M75-19-6 & 4.100 & 2.100 \\
\hline & M75-17- 8 & 4.000 & 2.000 \\
\hline & M50-50-0 & 3.950 & 1.950 \\
\hline & M50-48-2 & 3.800 & 1.800 \\
\hline & M50-46-4 & 3.750 & 1.750 \\
\hline & M50-44-6 & 3.650 & 1.650 \\
\hline & M50-42-8 & 3.550 & 1.550 \\
\hline & M25-75-0 & 3.450 & 1.450 \\
\hline & M25-73-2 & 3.250 & 1.250 \\
\hline & M25-71-4 & 3.150 & 1.150 \\
\hline & M25-69-6 & 3.000 & 1.000 \\
\hline & M25-67-8 & 3.000 & 1.000 \\
\hline & M0-100-0 & 3.000 & 1.000 \\
\hline & M0-98-2 & 2.950 & 0.955 \\
\hline & M0-96-4 & 2.750 & 0.950 \\
\hline & M0-94-6 & 2.650 & 0.850 \\
\hline & M0-92-8 & 2.35 & 0.750 \\
\hline
\end{tabular}

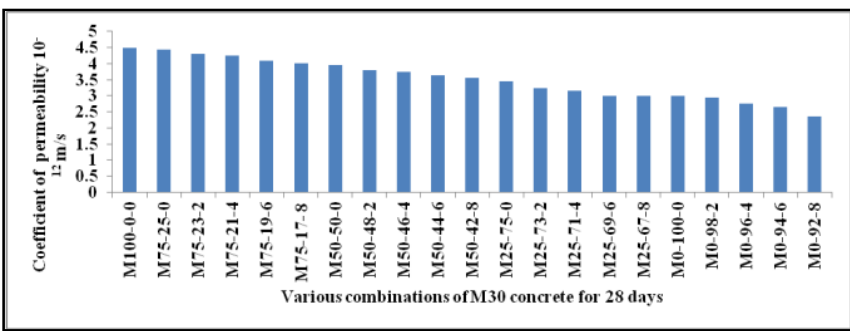

Figure 11 Coefficient of cracked permeability for M30 concrete at 28

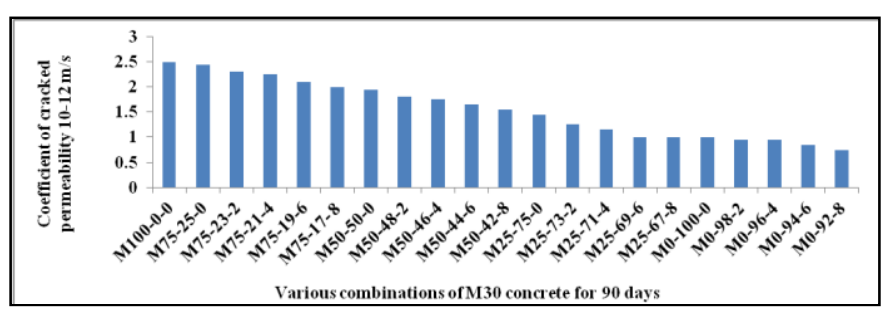

Figure 12 Coefficient of cracked permeability for M30 concrete at 90 days

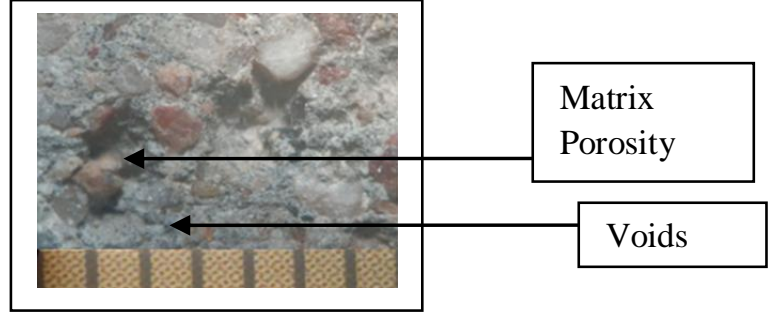

Figure13. Microscopic view of conventional concrete without initial stress (50x magnification).

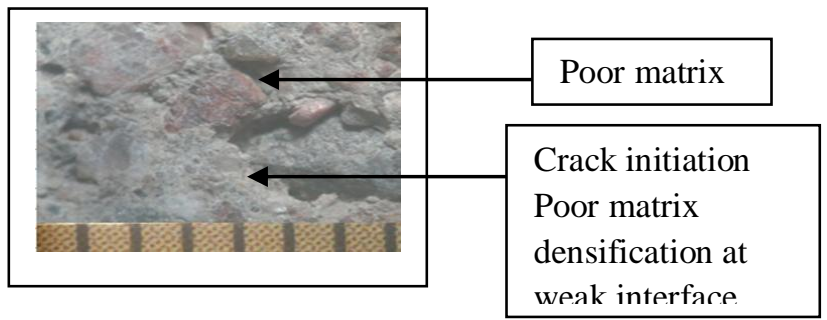

Figure14. Microscopic view of conventional concrete at $40 \%$ load (50x magnification).

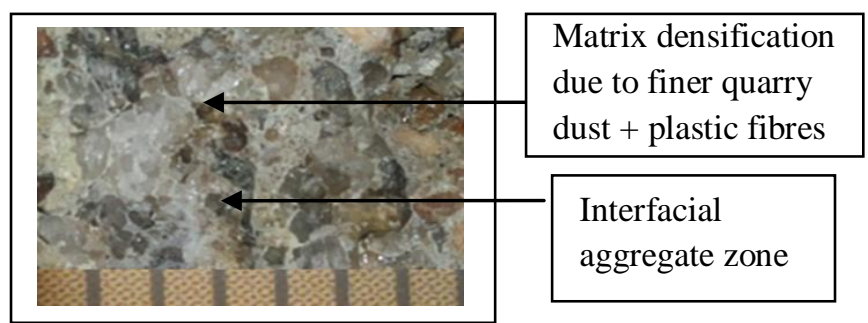

Figure15.Microscopic view of quarry dust concrete without stress (50x magnification).

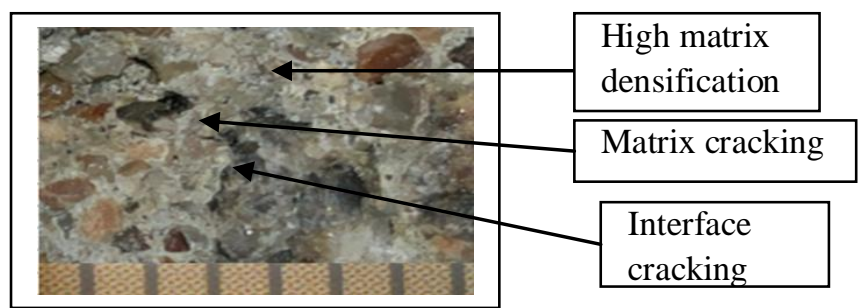

Figure16.Microscopic view of quarry dust concrete at $40 \%$ load (50x magnification).

\section{CONCLUSIONS:}

1. Quarry fines beneath $6 \mathrm{~mm}$ can be joined right right into a very last final results (for example, all out), be a thing of their non-public right (as an instance, top notch aggregate) or be surplus to promote demand, to be explicit plenitude fines which remain unused. The fines can be part of a immoderate diploma of extremely top notch (dust) debris (below $75 \mu \mathrm{m}$ ), which may additionally moreover in like manner be a piece of an absolute element, or be conveyed in plenitude, or be made for this reason. .

2. With artificial sands, crafted from sound severe shake, it is possible that the passing 75 micron material can be made out of finely ground shake flour with negligible harmful mineralogy. It's far feasible

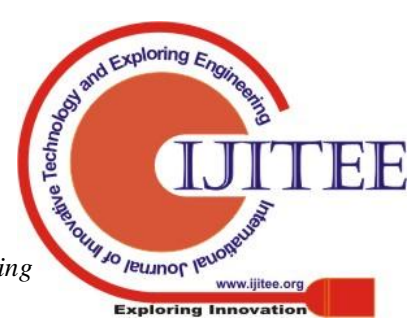


that excessive measures of dormant fines with a excessive express floor should even now purpose an extension in water call for. Regardless, the exams proven that idle, passing seventy five micron fines in added sand can skip about as filler and as a part of the folio, extending the usefulness of the mixture inside the plastic u. S . And diminishing porosity in the hardened state.

3. With the introduction of quarry dust there was unfaltering confirmation that an super piece of the passing $75 \mu \mathrm{m}$ substances could be ground fundamental minerals and not soil minerals. This material will bypass approximately as a stone flour or filler and can have focal factors in the strong mixture.

4. The broke permeability initial take a look at effects confirmed that the development of the quarry dust advanced the immersion restriction of concrete. This could be visible from the sturdy mixes containing one hundred\% quarry dirt as opposed to motion sand for the mixes M30 which confirmed a widespread lessening within the coefficient of vulnerability regards as a lot as $40 \%$, and the decline became primary for better robust substance $450 \mathrm{~kg} / \mathrm{m} 3$ ) in addition with recognize to $\mathrm{F} / \mathrm{C}$ quantity of 0 .Five.

5. It can in like manner be cited from the chloride permeability take a look at results that the doorway limit modified into better for quarry dirt concrete seemed differently in terms of conduit sand sturdy fashions. Regardless, it's miles shut from quarry dust nearby waste plastic strong that the permeability of concrete is managed on account of limit of the split taking off and calls for higher pressure for further beginning and multiplication.

6. That is clear from the element water vulnerability test outcomes further as chloride permeability take a look at effects. Differentiated and basic sand, $100 \%$ quarry dust substitution in bond exhibited the noteworthy lessening in broke vulnerability and chloride permeability at better strong substance and better F/C amount.

7. It's also fathomed from the atom degree examination that the fineness of quarry dirt incited the improved pore structure houses scary go segment densification houses. This is evidently visible from the propelled microscopy considers that the porosity of regular bond mixes had been more and done shape breaking but a complicated move segment densification is practiced with the quarry dirt substitution.

\section{REFERENCES:}

1. Bayasi, Z., Zeng, J. "residences of polypropylene fiber fortified concrete". ACI, materials mag 90 (6), 1993: 605610.

2. Zainab, Z. Ismail, E., Hashmi, A., "utilization of waste plastic in strong blend as whole replacement".S Waste control, 2007.

3. Ahn, N. Further, Fowler, D.W (2001). "An Experimental study on the hints for the use of better Contents of mixture Microfines in Portland Cement Concrete". ICAR-102-1S. All inclusive center for Aggregates studies (ICAR).

4. Fowler, Ahn and. "The consequences of excessive fines on the homes of concrete. ICAR 10th Annual." 2002.
5. Hudson, B. " "Made Sand - Destroying some Myths," Quarry pp. Fifty seven-sixty." 1997.

6. Hudson, B. "locating the out of place complete shot, factors 1 to 9, Pit and Quarry." 2003.

7. Sarkar, S.L., Aimin, X., Jana, D. "putting aside Electron Microscopy, X-Ray Microanalysis of Concretes," handbook of Analytical techniques in Concrete science and generation, (Ramachandran, V.E., Beaudoin, J.J., ed.), bankruptcy 7, William Andrew Publishing/Noyes courses, new york, 2001.

8. "IS: 10262:2009, "sturdy mix Proportioning - hints", First Revision, July." 2009.

9. "ASTM C 1202, fashionable test approach for electric Indicationcation of Concrete's potential to face up to Chloride Ion Penetration,American Society finding out of substances, Philadelphia, Pa, usa." 1979.

10. ASTM C 1202-1979. "fashionable take a look at technique for electric Indication of Concrete's capability to face up to Chloride Ion Penetration,American Society testing of substances, Philadelphia, Pa, americaa.."

11. IS 3085. Method for check for Permeability of Cement Mortarand Concrete, BIS famous, NewDelhi, India., 1965. 